DOI: 10.19085/journal.sijbpg031201

\title{
Indicator evaluation of regional innovation system according to the cluster approach
}

\author{
Kirill Uzlov and Tang Li-chun \\ South China University of Technology, School of Business Administration, Guangzhou, 381 Wushan Road, \\ China, 510641. \\ OScholedge International Journal of Business Policy \& Governance (ISSN 2394-3351), Vol.03, Issue 12 (2016) pg178-184. \\ Published by: Scholedge R\&D Center [www.theSCHOLEDGE.org] [Email: editorial@thescholedge.org]
}

\begin{abstract}
The need in the development, improvement, increasing the efficiency of regional innovation systems is especially relevant at the present time. In terms of global competition, attention is increasingly drawn to the regions as sources of competitiveness. The regional dimension allows to take into account the specifics and peculiarities of the separate territory, prevailing industry and other factors affecting to the development effectiveness in the region, and as a result, the country as a whole. The study of the processes of functioning and assessment of the level of the regional innovation system development due to the need to develop and substantiate the development management of regional innovation system for improving the population's quality of life through innovative development of economy, and as a result, change and modernization of the social sphere. Innovations, as one of the most important factors of economic development of the region, are the result of a number of targeted actions of the various parties of the innovation system, as well as a result effective functioning of its elements.
\end{abstract}

Keywords: regional innovation system, cluster, evaluation

\section{Introduction}

The effectiveness of countries as a whole is largely determined by the national innovation system, this regional perspective allows to take into account the specifics and peculiarities of the individual region, prevailing sectoral specialization of regions and other factors affecting effectiveness in the region development, and as a result, the country as a whole.

Intensive development of the economy is primarily connected with innovative reforms. In many regions of Russia the innovation processes are the basic processes that contribute to the development of the economy. However, to determine the role of innovative transformation is possible only by using special evaluation techniques that reflect the characteristics of the innovation processes in the regions.

The most appropriate technique is indicator assessment of innovative development of the region. It is based on a comprehensive assessment of an innovative susceptibility of region with use of indicators combined in clusters. Indicator assessment takes into account not only the resource characteristics of the region, but also includes advanced indicators of innovative development. Indicators carry important information for strategic management of regional innovation development. Group of indicators is formed by using correlation and regression method by selecting the most significant factors and indicators, which allows reducing the multidimensionality of assessment of region innovation susceptibility. 


\section{Research Background}

The development of regional innovation systems is an objective necessity and a feature of the process of the Russian economy modernization at the present stage. Interaction and cooperation between all participants of innovative process are necessary for the emergence of synergetic effect from interaction and for the creation of competitive advantages of individual members, groups and territorial formations.

The innovation process is not always predictable, and it often occurs in spurts, and the speed of innovation is also an important factor in economic development. In innovation processes there is important the role of community, collaboration and cooperation through which occurs the redistribution of resources and competences. The number of subjects of the innovation process and the number of interactions and connections between them affects on the level of development of the regional innovation system.

Concepts of interregional competition, the cluster approach, globally oriented regional policy, transnational integration; developing in the framework of the theory of competitive advantages of M. Porter (1998) come to replace the traditional theories of regional development.

Over time, it is understood that the region, acting as a control object, is a complex socio-economic system. Each Russian region has various unique benefits which, in turn, form an image of the subject, its economic independence and consequently determine the factor of competitiveness. Extensive raw growth of the region must be supplemented or replaced by an innovation-oriented (Ignatova, 2011).

At the present stage of human development, entrepreneurship and technology are the dominant factors of production. Competition among regions departs from the policy of "material production" and proceeds to the policy of "innovation and intelligence".

Innovation processes in regional systems is considered to be the basic processes that contribute to the development of the economy. Only the presence of necessary and sufficient conditions of innovation will allow us to develop innovative transformations (Kupriyanov, 2014). Currently, there are many assessment methodologies of innovative development, calculated according to general economic indicators or on the basis of the developed criteria at the level of industry or region (Beljakova, 2008). The multicriteria indicators of innovative activities make it difficult to assess the innovation process. On the one hand, the evaluation of all actions performed on numerous variables, expand the "assessment field", but on the other hand, complicate the procedure of assessment and analysis. In this case, the most appropriate may be the method of indicator planning (Vladimirova, 2010). Overall indicator approach fits in existing methods of assessment, but the task is broader: to assess the indicators of innovative development of the region as accurately as possible, to reduce the number of indicators, to be able to carry out a qualitative comparative analysis.

\section{Theoretical and practical significance}

Theoretical and practical significance of the indicator of innovative development of the region is that its value will identify the effectiveness of regional innovation resources.

Assessment and analysis of innovative development have become key aspects in the prognosis of further development of socio-economic processes and the nature of the changes in trends. In this case, the assessment of innovative development should be carried out taking into account the factors of influence to more accurately evaluate the one-time investments and operating costs for every percentage of regional income increase at the expense of development, deployment and use of innovation.

Each region is interested in establishing a favourable innovation climate, but faces real problems that require additional costs. Assessment of innovative development of the region will allow to 
obtain promising data for the use of innovative potential in the region. The innovation potential is a complex system of interacting resources, so the indicator rating will allow to reflect the innovation perspectives of regional development using a limited number of indicators.

Indicator assessment includes indicators of balance, the right balance between the elements of the regional innovative potential, opening opportunities for the creation of an economic system characterized by maximum productivity and efficiency.

\section{International experience}

Currently, there are a number of different foreign and international methodologies of assessment of innovation system in the region. In many methodologies for assessment the level and characteristics of innovative potential of regions there is used an integral coefficient as the final indicator. Integral gain allows to analyze and compare values in different regions.

Regional innovation system is assessment through innovative potential, innovative activity, innovative development. In international methodologies innovation system is often assessment through global indicators of competitiveness. This fact confirms the strong correlation of the innovation system and the competitiveness of the territory. Matches on a large number of parameters, used in these valuation techniques, allow to consider them together.

A well-known method of assessment the level of innovative economy development is a sub-index of innovation development of the global competitiveness index $(\mathrm{GCl})$, calculated for reports on global competitiveness by the world economic forum, global innovation index (GII), calculated by The Institute of business administration INSEAD and The Innovation Union Scoreboard (IUS).

The most well-known ratings of innovative development of countries are The European Innovation Scoreboard (EIS), The International Innovation Index (III), The Global Competitiveness Index (GCI), The Global Innovation Index (GII). At the regional level, the monitoring of innovation development in The European Union is presented as The Innovation Union Scoreboard (IUS), and in the US as Portfolio Innovation Index (PII).

For the assessment of innovative development of the EU regions there are used 16 indicators. Within IUS an absolute ranking of individual regions isn't applied, but there are allocated and prioritized the groups of regions with similar level of innovative development.

As the result of RIS assessment in the EU there are allocated five types of innovation territories: strong innovators, medium-strong innovators, medium innovators, medium-weak innovators.

Unfortunately, most of the above mentioned indicators of innovative potential assessment cannot be calculated in the Russian Federation in full measure, as the Russian statistics do not count for the required assessment indicators, which explains the fact that these techniques are not widely used in Russia. However, during development of the method for the RIS assessment there were considered the main approaches to the choice of indicators adopted abroad.

\section{Methodology}

For the development of the study methodology there were taken into account the main approaches to the assessment of innovation, innovation development, defined key indicators included in the structure of the integral index of innovative development by various researchers. However, for a comprehensive evaluation of the regional innovation system it is necessary to perform, to select and include the indicators used to measure the RIS in assessment cluster development. This analysis component is widely used in international practices, but it have not yet found wide application in the Russian approaches to the assessment of regional innovation systems. 
The aim of the proposed methodology of indicator assessment of the regional innovation system is to determine the level of development based on the proposed model of a regional innovation system (RIS).

To achieve this goal it is necessary to solve following tasks:

1. To establish a system of indicators to assess the RIS

2. Calculate particular RIS indicators;

3. To analyze the contribution of private indicators to the integral RIS index, their level of development, dynamics of change of the integral RIS index;

4. Predict the integral RIS index.

In the process of RIS analysis, generalized indicators have a great importance, as they give the opportunity to combine different partial indicators and bring them to a common denominator.

For the evaluation of regional innovation system as an integral RIS index there are defined 5 groups of indicators ( 33 private indicators), which represented by 5 private RIS indicators:

1. The indicator of the conditions of knowledge generation.

2. The indicator for the distribution and use of knowledge.

3. The indicator of cluster potential of the region.

4. The indicator of inclusion of the region into the world economy.

5. The indicator of socio-economic development of the region.

From the above mentioned analysis of methods of evaluation of RIS, common critical approach to the evaluation is to assess the RIS through innovation, innovative processes, innovative institutions. In the methodology, much attention is paid to indicators of innovative activities. The list of indicators by groups of indicators is presented in the Table below.

Table 1: Components of the integral index of the regional innovation system

\begin{tabular}{|c|c|c|}
\hline Indicator & Described fields & Indexes \\
\hline \multirow{8}{*}{$\begin{array}{l}\text { Conditions for } \\
\text { knowledge generation }\end{array}$} & \multirow{5}{*}{ th Innovation potential } & Costs on technological innovation to GRP, mln. RUB. \\
\hline & & $\begin{array}{l}\text { Costs on information and communication } \\
\text { technologies to GRP, mln. RUB. }\end{array}$ \\
\hline & & $\begin{array}{l}\text { Domestic costs on research and development to GRP, } \\
\text { mln. RUB. }\end{array}$ \\
\hline & & $\begin{array}{l}\text { The number of organizations performing research } \\
\text { and development, ed. }\end{array}$ \\
\hline & & $\begin{array}{l}\text { The proportion of organizations engaged in } \\
\text { innovation activity; } \% \text {. }\end{array}$ \\
\hline & \multirow[t]{3}{*}{ HR component } & $\begin{array}{l}\text { The number of employees engaged in research and } \\
\text { development and the number of employees in the } \\
\text { economy, (person). }\end{array}$ \\
\hline & & $\begin{array}{l}\text { The number of students of state and municipal higher } \\
\text { educational institutions per } 10,000 \text { population for the } \\
\text { period (person). }\end{array}$ \\
\hline & & Average monthly nominal wage per employee, RUB. \\
\hline
\end{tabular}




\begin{tabular}{|c|c|c|}
\hline \multirow{10}{*}{$\begin{array}{l}\text { Dissemination and use } \\
\text { knowledge }\end{array}$} & \multirow[t]{6}{*}{ Patent activity } & Filed applications for inventions (pcs). \\
\hline & & Issued patents for inventions (pcs). \\
\hline & & The ratio of issued/filed patents for inventions (pcs). \\
\hline & & Filed applications for utility models (pcs). \\
\hline & & Issued patents for utility models, (pcs). \\
\hline & & $\begin{array}{l}\text { The ratio of issued/filed patents for utility models, } \\
\text { (pcs). }\end{array}$ \\
\hline & \multirow[t]{4}{*}{$\begin{array}{l}\text { Realization of } \\
\text { innovation potential }\end{array}$} & $\begin{array}{l}\text { The number of created advanced production } \\
\text { technologies, (pcs).. }\end{array}$ \\
\hline & & $\begin{array}{l}\text { The number of used advanced production } \\
\text { technologies, }(\mathrm{pcs}) \text {. }\end{array}$ \\
\hline & & $\begin{array}{l}\text { The ratio of used/created advanced production } \\
\text { technologies, ( } \mathrm{pcs}) \text {. }\end{array}$ \\
\hline & & $\begin{array}{l}\text { The volume of innovative goods, works, services, } \% \\
\text { from total amount of shipped goods, performed } \\
\text { works, services; \%. }\end{array}$ \\
\hline \multirow[t]{3}{*}{ Cluster capacity } & Industry specialization & $\begin{array}{l}\text { GRP on fields of activities in the Russian GDP, } \\
\text { thousand RUB }\end{array}$ \\
\hline & \multirow[t]{2}{*}{$\begin{array}{l}\text { Localization ratio of } \\
\text { employment }\end{array}$} & $\begin{array}{l}\text { The share of employees in the regions by types of } \\
\text { activity }\end{array}$ \\
\hline & & The share of employees in Russia by types of activities \\
\hline \multirow[t]{5}{*}{$\begin{array}{l}\text { Involvement in the glob } \\
\text { economy }\end{array}$} & \multirow[t]{5}{*}{$\begin{array}{l}\text { Foreign-economic } \\
\text { development }\end{array}$} & $\begin{array}{l}\text { Total foreign investments in Russian regions, } \\
\text { thousand USD. }\end{array}$ \\
\hline & & Import per capita in the regions of Russia, mln. USD. \\
\hline & & Export per capita in the regions of Russia, mln. USD \\
\hline & & $\begin{array}{l}\text { The region's import share in the total Russian import, } \\
\text { mln. USD. }\end{array}$ \\
\hline & & $\begin{array}{l}\text { The region's export share in total exports of the } \\
\text { Russian Federation, mln. USD. }\end{array}$ \\
\hline \multirow{3}{*}{$\begin{array}{l}\text { Socio-economic } \\
\text { development }\end{array}$} & \multirow{3}{*}{$\begin{array}{l}\text { Economic } \\
\text { development }\end{array}$} & GRP to GDP, mln. RUB. \\
\hline & & $\begin{array}{l}\text { Fixed assets in the economy at the full account value } \\
\text { per employee in the economy, mln. RUB. }\end{array}$ \\
\hline & & $\begin{array}{l}\text { The degree of wear of fixed assets at the end of the } \\
\text { year, \% }\end{array}$ \\
\hline
\end{tabular}




\begin{tabular}{|c|c|}
\hline & $\begin{array}{l}\text { Investments in fixed capital per person employed, } \\
\text { mln. RUB. }\end{array}$ \\
\hline \multirow[t]{3}{*}{ Social development } & $\begin{array}{l}\text { The share of employment in the economy to the total } \\
\text { population }\end{array}$ \\
\hline & $\begin{array}{l}\text { The population with incomes above the subsistence } \\
\text { level, in \% to the total population for the period, \% }\end{array}$ \\
\hline & GRP per capita, over the period, RUB \\
\hline
\end{tabular}

Define the formula for calculating the integral index of RIS:

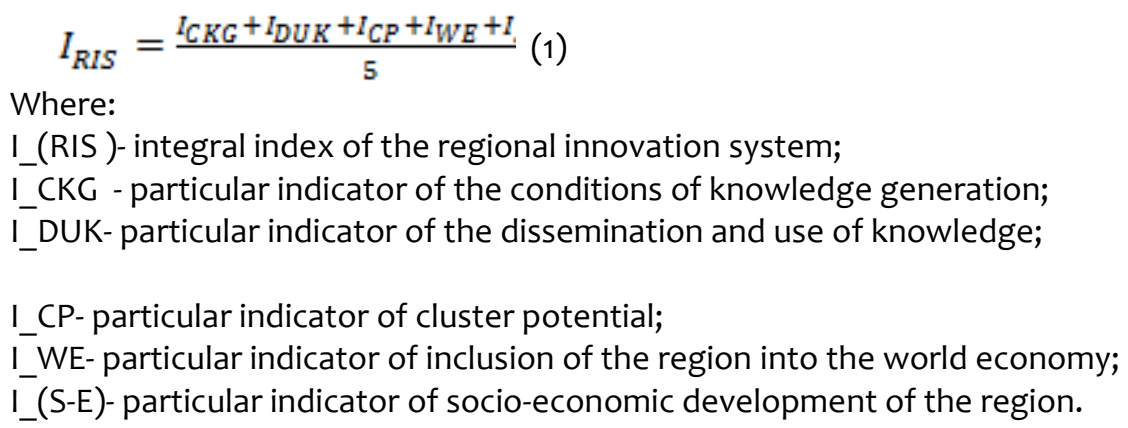

For calculation a particular indicator of a cluster potential in addition to the indicator of industry specialization there is calculated the coefficient of employment localization. The coefficient of localization is a frequently used indicator, which can be used to compare the economic characteristics of industries by number of employees, sales, GRP, etc. at regional or national levels. The value of the coefficient of localization indicates the dominant industry of the region, the dominant type of activity. The higher the coefficient, the greater the concentration is in a particular industry.

In the proposed methodology there is selected a sufficient number of indicators - 33 RIS indexes. The procedure of adjustment does not allow disproportionate distortion of the results, the proportional system allows to avoid expert subjectivity.

\section{Conclusion}

The selected indicators are widely used in various methods of estimation of innovative potential of the region, assessment of the regional innovation system in those combinations which meet the objectives of the study. The widespread use of similar indicators allows to speak about sufficient adequacy of the proposed methodology and the possible widespread use for practical purposes, and the use of integral indicators allows to approach objectively to the assessment of the regional innovation system.

\section{References}

[1] Porter M., (2005) 'The competitive advantage of nations', Publishing house «Williams»,. 608p. [2] Ignatova T.V., Cherkasova T.P., (2011) 'Innovation growth in Russia', Kaspijskij region: Policy, [3] Economy, Culture.. № 2. - pp. 178-186.

[4] Kupriyanov S.V., Stryabkova E.A., (2014) 'The place of cluster in the system of economic planning', Fundamental research, no. 3 (part 2), pp. 330-334. 
[5] Beljakova G.J., Sokolova E.L., (2008) 'Infrastructural providing of innovation development', SibGTU, p. 136.

[6] Vladimirova O.N., (2010) 'Innovative sensitivity as a factor of regional innovation system formation', Kreativnajaehkonomika.. no. 3, pp. 63-69.

[7] Kupriyanov S.V., Stryabkova E.A., Zarkovich A.V., (2014) 'Features assessment of regional innovation system with regard to the impact of cluster development', Economics science - № 9, p. 1057.

[8] Plotnikova T.N., Konyakhina T.B., Solomonova E.B., (2015) 'Indicative estimates innovative susceptibility region', Economics science - № 12, p. 181.

[9] Ivanova D.E., (2015) 'Indicative evaluation of innovative activity in the region through an econometric methodology of main components', SKAGS - № 1, p. 224.

[10] Mirolyubova T.V., (2009) 'Regional capacity of clusters development', PGNIU - №4., pp. 88-96. [11] www.gks.ru 